\title{
CARDIOVASCULAR PROFILE AFTER INTRAVENOUS INJECTION OF AFRICANIZED BEE VENOM IN AWAKE RATS
}

\author{
Janaína Valadares GUIMARÃES(1), Roberto Silva COSTA(2), Benedito Honório MACHADO(3) \& Marlene Antônia dos REIS(4)
}

\begin{abstract}
SUMMARY
The manifestations caused by Africanized bee stings depend on the sensitivity of the victim and the toxicity of the venom. Previous studies in our laboratory have demonstrated cardiac changes and acute tubular necrosis (ATN) in the kidney of rats inoculated with Africanized bee venom (ABV). The aim of the present study was to evaluate the changes in mean arterial pressure (MAP) and heart rate (HR) over a period of $24 \mathrm{~h}$ after intravenous injection of $\mathrm{ABV}$ in awake rats. A significant reduction in basal HR as well as in basal MAP occurred immediately after ABV injection in the experimental animals. HR was back to basal level 2 min after ABV injection and remained normal during the time course of the experiment, while MAP returned to basal level 10 min later and remained at this level for the next $5 \mathrm{~h}$. However, MAP presented again a significant reduction by the $7^{\text {th }}$ and $8^{\text {th }} \mathrm{h}$ and returned to the basal level by the $24^{\text {th }} \mathrm{h}$. The fall in MAP may contribute to the pathogenesis of ATN observed. The fall in MAP probably is due to several factors, in addition to the cardiac changes already demonstrated, it is possible that the components of the venom themselves or even substances released in the organism play some role in vascular beds.
\end{abstract}

KEYWORDS: Cardiovascular; Mean arterial pressure; Heart rate; Acute renal failure; Africanized bee venom.

\section{INTRODUCTION}

Africanized bees are hybrids between African and European bees which present a well-developed defensive behavior, attacking their victims in swarms and inoculating large amounts of venom ${ }^{27}$. Human victims of multiple stings manifest hemolysis, rhabdomyolysis, cardiotoxicity and acute renal failure (ARF) due to acute tubular necrosis (ATN), as well as changes in arterial pressure, hypotension ${ }^{6,9,18,22}$ and hypertension $^{3,9,16,19,25}$.

In our laboratories we have developed an experimental model involving Wistar rats inoculated intravenously (iv) with ABV. Rhabdomyonecrosis ${ }^{1}$, a greater release of cardiac noradrenaline (NAD) ${ }^{7}$ and lesion of the acute myocardial infarction (AMI) type have been demonstrated $^{8}$, as well as ARF due to ATN, with characteristics suggestive of both ischemic and toxic etiology. On the basis of previous experiments showing that $\mathrm{ABV}$ produces serious damage to the kidney and the heart, the aim of the present study was to evaluate the time course of the cardiovascular changes occurring in response to intravenous injection of $\mathrm{ABV}$ in awake rats.

\section{MATERIAL AND METHODS}

ABV was collected as described previously ${ }^{1}$ and inoculated iv at a dose of $0.4 \mu \mathrm{l} / 100 \mathrm{~g}$ body weight, diluted 1:500 in saline. The solution was stored at $4{ }^{\circ} \mathrm{C}$ and used within $24 \mathrm{~h}$ of venom collection. Male Wistar rats weighting 180-200 $\mathrm{g}$ were used in these experiments. One day before the experiments, the rats were anesthetized with tribromoethanol (250 $\mathrm{mg} / \mathrm{kg}$, Aldrich) and a catheter (PE-10 connected to PE-50, Clay Adams, Parsippany, NJ, USA) was inserted into the abdominal aorta through the femoral artery for measurement of pulsatile arterial pressure (PAP), mean arterial pressure (MAP) and heart rate (HR). Another catheter was inserted into the femoral vein for administration of $A B V$ or vehicle (saline). Both catheters were tunneled subcutaneously and exteriorized through the back of the neck to be connected to a pressure transducer during the experiments on the next day. PAP, MAP and HR were measured in awake freely moving rats placed inside a plastic box and the arterial catheter was connected to a pressure transducer (model CDXIII, Cobe, Lakewood, CO, USA) which was part of a Narcotrace 40 physiological recorder (Narco Bio-System, Austin, TX, USA). HR was counted with a Narco Biotachometer Coupler (model 7302) in the physiological recorder ${ }^{11}$. The experimental protocol consisted of intravenous injection of $\mathrm{ABV}$ in the experimental group $(n=12)$ and intravenous injection of vehicle (saline) in the control group $(n=9)$. MAP and HR were initially recorded for at least $20 \mathrm{~min}$ until complete adaptation of the rat to the environment of the acoustically isolated room used for cardiovascular records in awake rats. After the injection of $\mathrm{ABV}$ or saline, MAP and HR were continuously recorded for the next $30 \mathrm{~min}$ and then at the $4^{\text {th }}, 5^{\text {th }}, 7^{\text {th }}, 8^{\text {th }}$ and $24^{\text {th }} \mathrm{h}$ with a recording period of at least $15 \mathrm{~min}$ in each of these windows. 
At the end of the functional studies, the kidneys were removed and processed for light microscopy by staining with hematoxylin and eosin, Masson's trichrome, and periodic acid-methenamine-Schiff. Data were analyzed statistically by the Two Way Repeated Measures ANOVA followed by the Bonferroni t-test for all pairwise multiple comparison procedures, with the level of significance set at $5 \%(\mathrm{p}<0.05)$.

\section{RESULTS}

Functional study: Table 1 shows MAP and HR values for the control and experimental groups. Figure 1 shows that intravenous injection of the vehicle produced no significant change in MAP over a period of 24 $\mathrm{h}$, while $\mathrm{ABV}$ produced a significant fall in MAP within 5 min after its intravenous injection. During the period of time from $10 \mathrm{~min}$ to $5 \mathrm{~h}$ after $\mathrm{ABV}$ injection, MAP remained at the basal level but at the $7^{\text {th }}$ and $8^{\text {th }} \mathrm{h}$ MAP was again significantly reduced when compared to the basal level or to the level observed in control rats injected with vehicle. However, by the $24^{\text {th }} \mathrm{h}$ MAP was back to the basal level. Figure 2 shows that intravenous injection of vehicle produced no significant change in the HR over a period of $24 \mathrm{~h}$ while ABV produced a significant fall in HR immediately after injection (1 sec and $1 \mathrm{~min}$ ). However, 2 min later HR was back to the basal level and remained within this normal range for the next $24 \mathrm{~h}$.

Morphological Studies: No alterations were observed in the glomerular, interstitial, or vascular compartments of the kidney of the animals or in the tubular compartment of control animals. In contrast, in the tubular compartment of experimental animals there was acute tubular necrosis (ATN) characterized by tubular dilatation, casts and epithelial

Table 1

Distribution of mean arterial pressure (MAP) in mmHg and heart rate (HR) in bpm over a period of $24 \mathrm{~h}$ in Control and Experimental rats inoculated with Africanized bee venom

\begin{tabular}{lcccl}
\hline & \multicolumn{2}{c}{ MAP $(\mathrm{mmHg})$} & \multicolumn{2}{c}{ HR $(\mathrm{bpm})$} \\
Time & Control & Experimental & Control & Experimental \\
& $\mathrm{X} \pm \mathrm{SEM}$ & $\mathrm{X} \pm \mathrm{SEM}$ & $\mathrm{X} \pm \mathrm{SEM}$ & $\mathrm{X} \pm \mathrm{SEM}$ \\
\hline Basal & $105.0 \pm 1.3$ & $109.8 \pm 3.7$ & $398.7 \pm 12.5$ & $408.3 \pm 11.6$ \\
$1 \mathrm{sec}$ & $106.9 \pm 1.6$ & $65.0 \pm 5.0^{*}$ & $395.0 \pm 10.5$ & $217.9 \pm 37.2^{*}$ \\
$1 \mathrm{~min}$ & $108.1 \pm 2.1$ & $72.1 \pm 7.0^{*}$ & $385.0 \pm 12.2$ & $261.7 \pm 40.3^{*}$ \\
$2 \mathrm{~min}$ & $110.0 \pm 3.1$ & $71.7 \pm 7.4^{*}$ & $391.2 \pm 10.3$ & $421.7 \pm 18.4$ \\
$5 \mathrm{~min}$ & $108.1 \pm 2.7$ & $77.5 \pm 7.2^{*}$ & $397.5 \pm 10.1$ & $473.3 \pm 7.8$ \\
$10 \mathrm{~min}$ & $109.4 \pm 3.6$ & $97.9 \pm 9.0$ & $413.7 \pm 11.5$ & $465.8 \pm 7.0$ \\
$20 \mathrm{~min}$ & $113.7 \pm 2.5$ & $112.9 \pm 7.3$ & $410.0 \pm 13.6$ & $435.8 \pm 10.5$ \\
$30 \mathrm{~min}$ & $113.1 \pm 2.3$ & $116.2 \pm 7.0$ & $411.2 \pm 16.3$ & $435.0 \pm 12.3$ \\
$4 \mathrm{~h}$ & $108.7 \pm 2.6$ & $95.4 \pm 5.0$ & $438.7 \pm 14.3$ & $470.9 \pm 7.8$ \\
$5 \mathrm{~h}$ & $106.9 \pm 2.8$ & $96.8 \pm 7.2$ & $423.7 \pm 16.9$ & $464.5 \pm 7.5$ \\
$7 \mathrm{~h}$ & $112.5 \pm 3.3$ & $85.0 \pm 5.9 *$ & $372.5 \pm 18.5$ & $401.8 \pm 27.3$ \\
$8 \mathrm{~h}$ & $111.9 \pm 6.4$ & $80.9 \pm 8.3 *$ & $380.0 \pm 13.8$ & $395.4 \pm 34.2$ \\
$24 \mathrm{~h}$ & $120.0 \pm 3.1$ & $101.7 \pm 8.5$ & $408.7 \pm 14.8$ & $435.0 \pm 20.2$ \\
\hline
\end{tabular}

Results expressed as $\mathrm{X} \pm \mathrm{SEM}$. $\mathrm{Sec}=$ second, $\min =$ minute, $\mathrm{h}=$ hour. Two Way Repeated Measures ANOVA followed by Bonferroni t-test: * $p 0.05$ Control versus Experimental group. Time within experimental group, $\mathrm{p}<0.05$ : PAM: Basal versus: $1 \mathrm{sec}, 1 \mathrm{~m}, 2 \mathrm{~m}, 5 \mathrm{~m}, 7 \mathrm{~h}$ and $8 \mathrm{~h} ; 1 \mathrm{sec}$ versus: $10 \mathrm{~m}$ to $24 \mathrm{~h} ;(1 \mathrm{~m}$, $2 \mathrm{~m}, 5 \mathrm{~m}$ ) versus: $10 \mathrm{~m}, 20 \mathrm{~m}, 30 \mathrm{~m}, 4 \mathrm{~h}, 5 \mathrm{~h}$ and $24 \mathrm{~h}$; $(20 \mathrm{~m}$ and $30 \mathrm{~m})$ versus: $7 \mathrm{~h}$ and $8 \mathrm{~h}$. HR: $1 \mathrm{sec}$ and 1 min versus all other times.

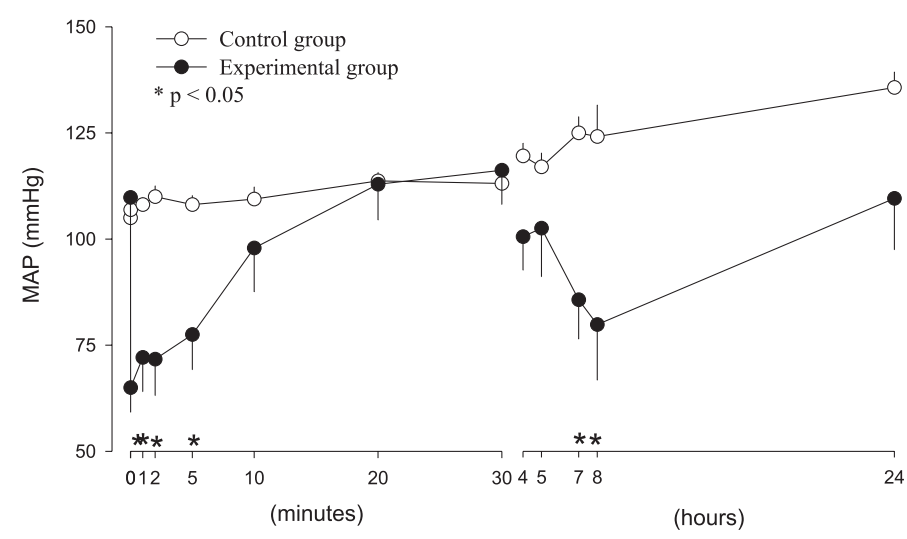

Fig. 1 - Mean Arterial Pressure (MAP - mmHg) in Control or Experimental group, injected with saline and Africanized bee venom, respectively, recorded during 24 hours.

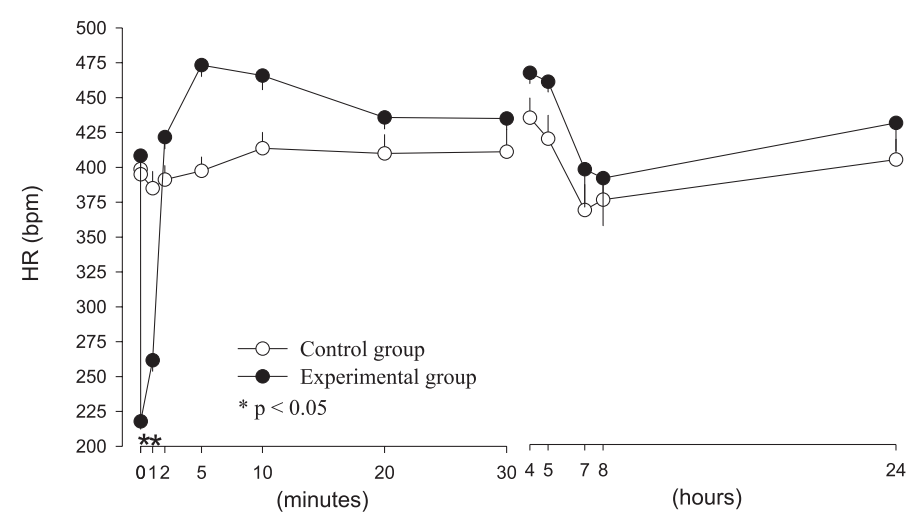

Fig. 2 - Heart rate (HR - bpm) in Control or Experimental group, injected with saline and Africanized bee venom, respectively, recorded during 24 hours.

cell necrosis, and mitosis in the tubular epithelium. This histological picture was the same reported in previous papers from our laboratory ${ }^{23,24}$.

\section{DISCUSSION}

Intravenous injection of $\mathrm{ABV}$ produced an intense bradycardic response which probably contributed, at least in part, to the significant fall in MAP observed immediately after the injection. This intense bradycardic response may be related to a possible direct effect of toxins of $\mathrm{ABV}$ on the pacemaker of the heart with a consequent reduction of heart rate in the initial period of envenomation. This major reduction in HR may affect the cardiac output with a consequent fall in MAP, which is consistent with the marked fall in MAP. Alternatively, we may suggest that $\mathrm{ABV}$ injection may stimulate terminals of the cardiopulmonary afferents in the heart and activate the Bezold-Jarisch reflex, which presents bradycardia and hypotension as a typical response due to sympathetic inhibition and parasympathetic excitation ${ }^{4,5,17}$. ABV contains histamine and serotonin ${ }^{10}$, which are used experimentally to activate the BezoldJarisch reflex $^{26}$.

Independently of the mechanisms that determine the fall in HR and MAP, it is important to note that HR was back to normal within 2 min, suggesting that no major damage to the pacemaker or the heart itself was 
produced by $\mathrm{ABV}$. In addition, MAP was back to the basal level within 10 min, indicating that $\mathrm{ABV}$ caused no major damage to the vascular beds and also that the reflex mechanisms were preserved considering that the initial fall in MAP led to the unloading of the arterial baroreceptors, with a consequent increase in the sympathetic activity to the heart as well as to the vascular beds contributing to the normalization of cardiovascular function. Another important aspect that we should consider in the normalization of MAP within $10 \mathrm{~min}$ is the possible involvement of the renin-angiotensin system, which probably contributed to an increase in vascular resistance and consequently to an increase in MAP.

An interesting question that remains to be answered is why MAP was significantly reduced by the $7^{\text {th }}$ and $8^{\text {th }} \mathrm{h}$ when compared to basal level or to the MAP observed at the same time points in the control group injected with saline. However, by the $24^{\text {th }} \mathrm{h}$ MAP was back to normal, indicating that this dose of $\mathrm{ABV}$ caused no major problems to the cardiovascular system other than the initial and abrupt fall in HR and MAP, which were buffered by physiological mechanisms within a time interval of $10 \mathrm{~min}$.

ABV is a complex mixture of substances, among them melittin, apamin, adrenaline (AD), noradrenaline (NAD), histamine and serotonin ${ }^{10}$. Endogenous AD and NAD secretion may be stimulated by the mellitin, phospholipase A2, histamine and serotonin present in ABV. These substances may provoke ischemia in the myocardium, as well as intense hypotension ${ }^{18}$. There are reports of changes in arterial pressure, hypertension have been described as part of the "autonomic storm" $3,9,16,19,25$, and especially hypotension, in human victims of multiple Africanized bee stings ${ }^{6,9,22}$, as well as acute myocardial infarction $(\mathrm{AMI})^{13,18}$. Delayed reactions occurring only $18 \mathrm{~h}$ after envenomation have also been reported, with a rapid course and multiple organ failure ${ }^{16}$.

Previous studies from our laboratory carried out on Wistar rats have demonstrated electrocardiographic (ECG) ${ }^{2}$ and enzymatic ${ }^{7}$ changes and morphological lesion of the AMI type ${ }^{8}$, showing a possible direct toxic action of the venom on cardiac muscle. Using monkey cardiomyocytes in culture ${ }^{21}$, it was demonstrated that previous treatment of bee venom with anti-melittin antibody eliminated the cardiotoxicity, suggesting that this lesion may be mainly due to melittin. Administration of whole Apis mellifera venom to dogs and cats at doses above $1 \mathrm{mg} / \mathrm{kg}$ weight provokes an immediate fall in MAP to the level of irreversible shock, with lower doses of the venom possibly having a stimulatory effect on the heart. In this same study, ECG changes indicated a direct lesion of the myocardiocyte membrane ${ }^{15}$. In addition, it has been demonstrated that at concentrations of 0.5 to $2 \mu \mathrm{g} / \mathrm{ml}, \mathrm{ABV}$ caused a decrease in HR in isolated perfused toad heart. This bradycardia was accompanied by lengthening of the P-R interval. A gradual and progressive increase in $\mathrm{R}$-wave amplitude reflected a positive inotropism of the venom. Also, changes were observed in the ECG, like marked injury current, elevation or depression of the S-T segment, atrioventricular conduction disturbances and sinus arrhythmias. Atropine and nicotine may decrease the toxic effect of the venom on the myocardium. The present results lead us to suggest that the effect of $A B V$ is mediated through the peripheral cholinergic neurotransmitter system ${ }^{20}$.

In addition to the cardiac changes already demonstrated in Wistar rats, it is possible that the components of the venom themselves or even substances released in the organism play some role in peripheral arteriolar resistance, possibly contributing to the changes in MAP. ABV, in addition to containing several vasoactive components ${ }^{10}$, contains melittin, a polypeptide toxin known to mobilize arachidonic acid from the cell membrane. Melittin evokes endothelium-derived hyperpolarizing factortype relaxation by activation of endothelial $\mathrm{Ca} 2+$-dependent phospholipase $\mathrm{A}_{2}$ followed by the transmission of a chemical and/or electrical signal via myoendothelial gap junctions. This mechanism of vasorelaxation may be negatively regulated by nitric oxide ${ }^{14}$.

In the present study we observed ATN, as also observed in previous studies $^{23,24}$. Several factors are hypothesized to participate in the pathogenesis of ATN: 1) a direct toxic effect of ABV on renal tubules, especially proximal tubules ${ }^{12,23,24} ; 2$ ) a toxic effect of myoglobin and hemoglobin on the tubules ${ }^{7,24} ; 3$ ) an ischemic effect mediated by AVB or by substances released in the organism, or by a fall in cardiac output due to AMI-like lesions ${ }^{8}$ with a consequent fall in MAP reducing renal plasma flow, and 4) a stress-potentiating effect acting, for example, on NAD release in the myocardium ${ }^{7}$ aggravating the cardiac ischemic component and consequently renal perfusion.

The fall in MAP probably is due to several factors, in addition to the cardiac changes already demonstrated in Wistar rats, it is possible that the components of the venom themselves or even substances released in the organism play some role in peripheral arteriolar resistance, possibly contributing to the changes in MAP.

\section{RESUMO}

\section{Perfil cardiovascular após a inoculação intravenosa de veneno de abelha africanizada em ratos acordados}

As manifestações causadas por picadas de abelhas africanizadas dependem da sensibilidade da vítima e da toxicidade do veneno. Estudos anteriores em nosso laboratório mostraram alterações cardíacas e necrose tubular aguda (NTA) nos rins de ratos inoculados com veneno de abelhas africanizadas (VAA). O objetivo do presente estudo foi avaliar as alterações na pressão arterial média (PAM) e na freqüência cardíaca (FC) num período de 24 horas após a inoculação de VAA em ratos mantidos acordados. Uma redução significante na FC basal e na PAM ocorreu imediatamente após a inoculação de VAA nos animais experimentais. A FC voltou aos níveis basais 2 min após a inoculação do VAA e permaneceu nestes valores durante o restante do experimento, enquanto que a PAM voltou aos níveis basais $10 \mathrm{~min}$ após a inoculação e permaneceu nestes níveis pelas próximas 5 horas. Por outro lado, a PAM apresentou uma nova diminuição significante nas $7^{\mathrm{a}} \mathrm{e} 8^{\mathrm{a}}$ horas retornando aos níveis basais na $24^{\mathrm{a}}$ hora. A queda na PAM nos animais inoculados com VAA deve contribuir na patogênese da NTA observada nos rins destes animais. Provavelmente a queda da PAM seja multifatorial, além das alterações cardíacas já demonstradas, os próprios componentes do veneno e/ou substâncias liberadas no organismo podem atuar na resistência vascular, contribuindo para alterações na pressão arterial.

\section{ACKNOWLEDGEMENTS}

We are grateful to E.P.D. Gual, A.L.G. de Almeida, L. Bonagamba, J. Castania, M. Oliveira, and V.J.D. Silva for technical assistance. Research partially supported by FAPESP. RS Costa, BH Machado and MA dos Reis are recipients of CNPq grants. 


\section{REFERENCES}

1. AZEVEDO-MARQUES, M.M.; FERREIRA, D.B. \& COSTA, R.S.- Rhabdomyonecrosis experimentally induced in Wistar rats by Africanized bee venom. Toxicon, 30: 344348, 1992.

2. BESTETTI, R.; FERREIRA, D.B.; COSTA, R.S. et al. - Electrocardiographic changes evoked by injection of Africanized bee venom in Wistar rats. J. Molec. cell. Cardiol., 23(suppl. 5): S81, 1991.

3. BRESOLIN, N.L.; CARVALHO, L.C.; GOES, E.C.; FERNANDES, R. \& BAROTTO, A.M. - Acute renal failure following massive attack by Africanized bee stings. Pediat. Nephrol., 17: 625-627, 2002.

4. CHIANCA Jr., D.A. \& MACHADO, B.H. - The sensitivity of the Bezold-Jarisch reflex is increased in rats with sinoaortic deafferentation. Braz. J. med. biol. Res., 27: 775-781, 1994

5. CHIANCA Jr, D.A.; BONAGAMBA, L.G.H. \& MACHADO, B.H. - Neurotransmission of the Bezold-Jarisch reflex in the nucleus tractus solitarii of sino-aortic deafferentated rats. Brain Res., 756: 46-51, 1997.

6. DAHER, E.F.; SILVA JUNIOR, G.B.; BEZERRA, G.P. et al. - Acute renal failure after massive honeybee stings. Rev. Inst. Med. trop. S. Paulo, 45: 45-50, 2003.

7. FERREIRA, D.B.; COSTA, R.S.; OLIVEIRA, J.A.M. \& MUCCILLO, G. - Cardiac noradrenaline in experimental rat envenomation with Africanized bee venom. Exp. Toxic. Path., 45: 507-511, 1994.

8. FERREIRA, D.B.; COSTA, R.S.; OLIVEIRA, J.A.M. \& MUCCILLO, G. - An infarctlike myocardial lesion experimentally induced in Wistar rats with Africanized bee venom. J. Path., 175: 95-102, 1995.

9. FRANÇA, F.O.S.; BENVENUTI, L.A.; FAN, H.W. et al. - Severe and fatal mass attacks by "killer" bees (Africanized honey bees - Apis mellifera scutellata) in Brazil: clinicopathological studies with measurement of serum venom concentrations. Quart. J. Med., 87: 269-282, 1994

10. HABERMANN, E. - Bee and wasp venoms. Science, 177: 314-322, 1972.

11. HAIBARA, A.S.; COLOMBARI, E.; CHIANCA Jr., D.A.; BONAGAMBA, L.G.H. \& MACHADO, B.H. - NMDA receptors in NTS are involved in bradycardic but not in pressor response of chemoreflex. Amer. J. Physiol., 269: H1421-H1427, 1995.

12. HAN, H.J.; LEE, J.H.; PARK, S.H. et al. - Effect of bee venom and its melittin on apical transporters of renal proximal tubule cells. Kidney Blood Press. Res., 23: 393-399, 2000 .

13. HENRY, B.; FREYE, M.D. \& BRIAN EHRLICH, M.D. Acute myocardial infarction following hymenoptera envenomation. Allergy Proc., 10: 119-126, 1989.
14. HUTCHESON, I.R. \& GRIFFITH, T.M. - Role of phospholipase $\mathrm{A}_{2}$ and myoendothelial gap junctions in melittin induced arterial relaxation. Europ. J. Pharmacol., 406: 239-245, 2000.

15. KAPLINSKY, E.; ISHAY, J.; BEM-SHACHAR, D. \& GITTER, S. - Effects of bee (Apis mellifera) venom on the electrocardiogram and blood pressure. Toxicon, 15: 251256, 1977.

16. KOLECKI, P. - Delayed toxic reaction following massive bee envenomation. Ann. emerg. Med., 33: 114-116, 1999.

17. MARK, A.L. - The Bezold-Jarisch reflex revisited: clinical implications of inhibitory reflexes originating in the heart. J. Amer. Coll. Cardiol., 1: 90-102, 1983.

18. MJOY, E.J. - Acute myocardial infarction after a wasp sting. Brit. Heart J., 59: 506-508, 1988.

19. MUÑOZ-ARIZPE, R.; VALENCIA-ESPINOZA, L.; VELÁSQUEZ-JONES, L. et al. Africanized bee stings and pathogenesis of acute renal failure. Nephron, 61: 478 , 1992.

20. NABIL, Z.I.; HUSSEIN, A.A.; ZALAT, S.M. \& RAKHA, M.K. - Mechanism of action of honey bee (Apis mellifera L.) venom on different types of muscles. Hum. exp. Toxicol., 17: 185-190, 1998.

21. OKAMOTO, T.; ISODA, H.; KUBOTA, N. et al. - Melittin cardiotoxicity in cultured mouse cardiac myocytes and its correlations with calcium overload. Toxicol. appl. Pharmacol., 133: 150-163, 1995.

22. OLIVEIRA. F.A.; GUIMARÃES, J.V.; REIS, M.A. \& TEIXEIRA, V.P. - Human accidents for stings of Africanized bees. Rev. Soc. bras. Med. trop., 33: 403-405, 2000.

23. REIS, M.A.; COSTA, R.S.; COIMBRA, T.M.; DANTAS, M. \& GOMES, U.A. - Renal changes induced by envenomation with Africanized bee venom in female Wistar rats. Kidney Blood Press. Res. 20: 271-277, 1997.

24. REIS, M.A.; COSTA, R.S.; COIMBRA, T.M. \& TEIXEIRA, V.P. - Acute renal failure in experimental envenomation with Africanized bee venom. Ren. Fail., 20: 39-51, 1998

25. SERT, M.; TETIKER, T. \& PAYDAS, S. - Rhabdomyolysis and acute renal failure due to honeybee sting as an uncommon cause. Nephron, 65: 647, 1993.

26. THOREN, P. - Role of the cardiac vagal C-fibers in cardiovascular control. Rev. Physiol. Biochem. Pharmacol., 86: 1-94, 1979.

27. VETTER, R.S.; VISSCHER, P.K. \& CAMAZINE, S. - Mass envenomations by honey bees and wasps. West. J. Med., 170: 223-227, 1999.

Received: 07 May 2003

Accepted: 16 January 2004 